Agata Poczmańska, Roksana PierWieniecka

Instytut Badań Edukacyjnych, Warszawa, Polska - Educational Research Institute, Warsaw, Poland

\title{
Edukacja przedsiębiorczości w ramach kształcenia zawodowego a sytuacja jego absolwentów na rynku pracy
}

\author{
Entrepreneurship Education in Vocational Education and Training and the VET \\ Graduates' Situation on the Labor Market
}

\begin{abstract}
Streszczenie: Zamierzeniem autorek artykułu jest wskazanie celów i metod kształcenia przedsiębiorczości, które pozwalają najlepiej przygotowywać uczniów w ramach kształcenia zawodowego do wejścia na rynek pracy. W doborze najefektywniejszych celów i metod uwzględniono kontekst edukacji zawodowej w Polsce oraz sytuację na polskim rynku pracy. W artykule dokonano przeglądu i analizy literatury prezentującej wyniki badań w przedmiotowym obszarze. Analizie poddano relacje między kształtowaniem postawy przedsiębiorczej a poziomem bezrobocia i skalą zakładania działalności gospodarczej w omawianej grupie osób. Wskaźniki te oraz wyniki innych badań skonfrontowano z kluczowymi elementami edukacji w zakresie przedsiębiorczości, którymi są formy i cele nauczania oraz metody kształcenia, powiązane również z kompetencjami nauczycieli i współpracą szkół z przedsiębiorcami. Ujęcie teoretyczne tych zagadnień i prezentacja wyników badań wzbogacone zostały o ujęcie praktyczne, czyli o przykłady rozwiązań stosowanych w Europie, ze szczególnym uwzględnieniem sytuacji w Polsce. Podsumowanie i wnioski z analizy uzupełnia zarys korzystnych w tym kontekście kierunków ewolucji edukacji przedsiębiorczości.
\end{abstract}

\begin{abstract}
The article aims to indicate the teaching objectives and methods within the entrepreneurship education that are most suitable in preparing VET students to enter the labour market. In selection of most efficient objectives and methods, the context of Polish vocational education and situation in labour market have been taken into account. For this purpose the literature presenting research findings in this area has been reviewed and analysed. The connections between shaping an entrepreneurial attitude, the level of unemployment, and the extent to which VET graduates started a business have been analysed. Those economic indicators and research findings were confronted with the key elements of entrepreneurship education: forms of learning and educational objectives in entrepreneurship education and teaching methods, which are connected with teachers' competences and forms of cooperation between learning providers and entrepreneurs. The theoretical approach and presentation of the research findings are supplemented by a practical approach - examples of different European solutions, with an emphasis on those used in Poland. Summary and conclusions from the analysis are supplemented by an outline of changes that could shape the evolution of entrepreneurship education.
\end{abstract}

Słowa kluczowe: absolwenci szkół zawodowych; edukacja przedsiębiorczości; kształcenie zawodowe; metody nauczania; przedsiębiorczość; rynek pracy 
Key words: entrepreneurship; entrepreneurship education; labor market; teaching methods; vocational education and training; vocational schools graduates

Otrzymano: 25 października 2015

Received: 25 October 2015

Zaakceptowano: 13 marca 2016

Accepted: 13 March 2016

\section{Sugerowana cytacja/Suggested citation:}

Poczmańska, A., Pierwieniecka, R. (2016). Edukacja przedsiębiorczości w ramach kształcenia zawodowego a sytuacja jego absolwentów na rynku pracy. Przedsiębiorczość - Edukacja, 12, 391-404.

\section{Wstęp}

Temat edukacji przedsiębiorczości jest często omawiamy na polskim gruncie naukowym. Traktuje się go zazwyczaj wąsko, badając odrębnie cele kształcenia przedsiębiorczości (Rachwał i in., 2008; Rachwał, 2009; Dorocki, Kilar, Rachwał, 2011), dydaktykę nauczania przedsiębiorczości (Desperak, Depczyńska, 2007; Tracz, Rachwał, 2008) czy treści przedmiotowe przedsiębiorczości (Piróg, 2005). Badania te w większości odnoszą się do kształcenia przedsiębiorczości w ramach edukacji ogólnej, czasem szkolnictwa wyższego (Borowiec, 2008; 2009; Piróg, 2010, 2015). Dostępne są też analizy w ujęciu teoretycznym, prowadzone w oderwaniu od typu kształcenia, w ramach którego prowadzone jest nauczanie przedsiębiorczości (Klucznik-Törő, 2012; Zioło, 2012).

W niniejszym artykule kształcenie przedsiębiorczości poddano analizie z perspektywy kształcenia zawodowego ${ }^{1}$ - nie tylko ze względu na swego rodzaju niszę badawczą, ale przede wszystkim ze względu na znaczenie, jakie edukacja ta może mieć dla sytuacji absolwentów kształcenia zawodowego na rynku pracy. Obecnie sytuacja ta wymaga w Polsce zdecydowanej poprawy.

Przez poprawę sytuacji tych osób na rynku pracy rozumie się przede wszystkim zmniejszanie wśród nich bezrobocia i podnoszenie poziomu zakładania przez nie działalności gospodarczej. Istnieje wiele metod badania przedsiębiorczości i efektywności edukacji przedsiębiorczości (OECD, 2009; Raczyk, 2009; Cieślik, 2014), jednak wybrane wskaźniki są nie tylko mierzalne, lecz także istotne ze społeczno-gospodarczego punktu widzenia. Dla osiągnięcia tak określonego celu dokonano przeglądu i analizy literatury prezentującej wyniki badań w przedmiotowym obszarze.

Zamierzeniem autorek artykułu jest wskazanie celów i metod kształcenia przedsiębiorczości, które pozwalają najlepiej przygotowywać uczniów w ramach kształcenia zawodowego do przyszłej pracy (rozwijają w nich samodzielność, kreatywność i dobrą organizację pracy). W doborze najefektywniejszych celów i metod uwzględniono kontekst edukacji zawodowej w Polsce oraz sytuację na polskim rynku pracy.

${ }^{1}$ W artykule termin „kształcenie zawodowe” definiowany jest zgodnie z Ustawa z dnia 19 sierpnia 2011 r. o zmianie ustawy o systemie oświaty oraz niektórych innych ustaw (Dz.U. z 2011 r. Nr 205, poz. 1206), która weszła w życie we wrześniu 2012 r. Zgodnie z ustawą kształcenie zawodowe odbywa się w następujących typach szkół: trzyletniej zasadniczej szkole zawodowej, czteroletnim technikum, szkole policealnej dla osób posiadających wykształcenie średnie oraz trzyletniej szkole specjalnej, której ukończenie umożliwia uzyskanie świadectwa potwierdzającego przysposobienie do pracy. 
Metody nauczania są jednym z czynników mających wpływ na efektywność procesu kształcenia. W niniejszym artykule omówiono je, odnosząc się do sposobu, w jaki proces ten jest zorganizowany i realizowany. Analiza teoretyczna została uzupełniona przykładami rozwiązań stosowanymi w Europie, ze szczególnym uwzględnieniem sytuacji w Polsce. Podsumowanie i wnioski z analizy uzupełnia zarys korzystnych w tym kontekście kierunków ewolucji edukacji przedsiębiorczości.

\section{Rynek pracy a sytuacja osób z wykształceniem zawodowym}

Kształcenie w zakresie przedsiębiorczości ma szczególne znaczenie w ramach kształcenia zawodowego, ponieważ absolwenci szkół zawodowych czy technikum są najbliżej wejścia na rynek pracy. W Polsce $20 \%$ uczniów szkół zawodowych deklaruje, że po zakończeniu szkoły podejmie pracę zawodową, a 48\%, że podejmie pracę zawodową i jednocześnie będzie kontynuować naukę (Ministerstwo Edukacji Narodowej..., 2011).

Warto zaznaczyć, że absolwenci szkół zawodowych są silnie związani z sektorem mikro-, małych i średnich przedsiębiorstw (MŚP) (Barabasch, 2014). Znacząca większość tych firm prowadzi działalność, na rzecz której odbywa się kształcenie w szkołach zawodowych. Firmy należące do sektora MŚP stanowią 99,8\% wszystkich przedsiębiorstw w Polsce, a sytuacja w innych państwach Unii Europejskiej wygląda podobnie (European Commission, 2014). Tym samym edukacja w ramach kształcenia zawodowego powinna mieć silne przełożenie na gospodarkę całego kraju, jak również na rozwój układów lokalnych. To właśnie w sektorze MŚP absolwenci kształcenia zawodowego będą najczęściej znajdować zatrudnienie lub zakładać własne firmy.

Tymczasem obecna sytuacja absolwentów kształcenia zawodowego na polskim rynku pracy nie jest dobra. Z Badania Aktywności Ekonomicznej Ludności (BAEL), według stanu na IV kwartał 2014 r., wynika, że stopa bezrobocia wśród absolwentów z wykształceniem zawodowym wynosi $37,3 \%$. Wśród wszystkich bezrobotnych osoby, które ukończyły zasadnicze kształcenie zawodowe, stanowią ponad $31 \%$, a wśród biernych zawodowo prawie $22 \%$ to osoby $\mathrm{z}$ wykształceniem zawodowym (GUS, 2015a).

$\mathrm{Z}$ badania przeprowadzonego w ramach programu Bilans Kapitału Ludzkiego (BKL) wynika, że jedynie 3\% mężczyzn i 1\% kobiet wśród bezrobotnych młodych (do 30 roku życia) absolwentów szkół zawodowych preferuje własną działalność jako formę przyszłego zatrudnienia, natomiast ponad $90 \%$ woli pracę etatową. Ostatecznie działalność zakłada 3\% młodych absolwentów. Wśród osób starszych (powyżej 30 roku życia) odsetek ten jest niewiele wyższy i wynosi 5\% (Jelonek, Kasparek, Magierowski, 2015). Badanie BKL wykazało silną korelację między poziomem wykształcenia a zakładaniem własnej firmy. Przykładowo, wśród osób młodych (do 30. roku życia) z wykształceniem wyższym 13\% założyło swoją firmę, zaś wśród młodych absolwentów szkół średnich odsetek ten wynosi 10\% (Jelonek, Kasparek, Magierowski, 2015 ).

Wydawać by się mogło, że właśnie ta grupa społeczna - osoby z wykształceniem zawodowym - nie powinna mieć problemów ze znalezieniem zatrudnienia czy z założeniem dobrze prosperującej firmy, ponieważ osoby te posiadają wykształcenie dające konkretny fach w ręku, a na rynku obserwujemy wysoki popyt na wykwalifikowanych fachowców. Jednak jak pokazują powyższe dane statystyczne, absolwenci szkół zawodowych nie tylko nie najlepiej radzą sobie na rynku pracy w kontekście pracy etatowej, lecz także rzadko myślą o założeniu własnej 
firmy czy samozatrudnieniu lub nie mają świadomości, że jest to dla nich korzystna alternatywa. Możliwe również, że nie są lub nie czują się odpowiednio do tego przygotowani.

Przyczyny takiego stanu rzeczy mogą być związane z ogólną sytuacją na polskim rynku pracy, ze stanem polskiego kształcenia zawodowego, jak również z ograniczeniami w kontekście zakładania działalności gospodarczej. Elementy te są istotne dla niniejszego artykułu, ponieważ edukacja przedsiębiorczości (a szczególnie stosowane w niej metody) powinna brać je pod uwagę, tj. odpowiadać na potrzeby rynku pracy oraz uwzględniać specyfikę i cele kształcenia zawodowego w Polsce.

Jak wspomniano wcześniej, stopa bezrobocia wśród osób z wykształceniem zawodowym jest stosunkowo wysoka. Dla uzupełnienia obrazu sytuacji warto przywołać pewne fakty dotyczące struktury polskiego rynku pracy. Od lat dominuje na nim sektor usług (w 2013 r. pracowało w nim ponad $3 \mathrm{mln}$ osób, co stanowiło 35,2\% ogółu zatrudnionych w przedsiębiorstwach prywatnych ${ }^{2}$ ), na drugim miejscu plasuje się przemysł (w 2013 r. w tym sektorze pracowało 2,8 mln osób, co stanowiło 31,3\% ogółu zatrudnionych w przedsiębiorstwach prywatnych), zaś na trzecim - handel (w 2013 r. pracowało w tym sektorze 2,2 mln osób, czyli 24,3\% ogółu zatrudnionych w przedsiębiorstwach prywatnych) (Tarnawa, Zadura-Lichota, 2015). Stopa bezrobocia rejestrowanego w grudniu 2013 r. wyniosła 13,4\% (GUS, 2015c). W tym samym czasie stopa bezrobocia wśród młodzieży (do 25 roku życia) wynosiła $27,2 \%$, co przewyższało ówczesną średnią w UE, wynoszącą 23,1\%³ (Eurostat, 2015). W grudniu 2015 r. stopa bezrobocia spadła do 9,8\% (GUS, 2015c). Obniżyło się także bezrobocie wśród młodzieży - w grudniu 2015 r. wynosiło 20,5\% (przy średniej dla UE wynoszącej 19,8\%) (Eurostat, 2016).

Jednocześnie w 2015 r. pogłębił się spadek współczynnika aktywności zawodowej (WAZ) w Polsce. Za jedną z kluczowych przyczyn tej zmiany uważa się obniżenie współczynnika aktywności osób w wieku przedemerytalnym. Do obniżenia WAZ przyczyniła się także malejąca aktywność najmłodszych uczestników rynku pracy (Cichocki i in., 2015) ${ }^{4}$. W tej właśnie grupie znajdują się młodzi absolwenci szkół zawodowych i technikum.

Przyczyn stosunkowo złej sytuacji osób z wykształceniem zawodowym na polskim rynku pracy jest wiele. Część z nich może być powiązana z systemem szkolnictwa zawodowego. Po 1989 r. rozpoczęła się reforma systemu kształcenia, m.in. zlikwidowano wiele zasadniczych szkół zawodowych, do których uczęszczała wówczas bardzo duża część młodzieży, i zaczęto tworzyć nowe technika i licea ogólnokształcące ${ }^{5}$. Kolejne reformy zmierzały w kierunku restrukturyzacji i modernizacji szkolnictwa zawodowego oraz zwiększenia udziału młodzieży

${ }^{2}$ Liczba osób pracujących w gospodarce narodowej wynosiła w 2013 r. 14,2 mln. W przedsiębiorstwach prywatnych pracowało 8,9 mln osób (Tarnawa, Zadura-Lichota, 2015).

${ }^{3}$ Ogólna stopa bezrobocia w Unii Europejskiej w ciągu ostatnich 5 lat wynosiła średnio ok. 9\%, podczas gdy stopa bezrobocia wśród osób do 25. roku życia średnio ponad 20\% (Eurostat, 2015). Warto pamiętać, że do wskaźnika wlicza się także osoby uczące się i studiujące, a wskaźnik skolaryzacji w Polsce jest bardzo wysoki na tle innych państw UE.

${ }^{4} \mathrm{~W}$ ujęciu terytorialnym (stan na wrzesień 2015 r.) najgorszą sytuację obserwuje się w województwie warmińsko-mazurskim (ogólna stopa bezrobocia wyniosła ponad 13,8\%). W województwie podlaskim, zachodniopomorskim, kujawsko-pomorskim, świętokrzyskim i podkarpackim sytuacja jest również trudna, gdyż stopa bezrobocia wynosi tam od 11,3\% do 13,7\%. Na terenie województwa pomorskiego, lubelskiego, lubuskiego, łódzkiego i opolskiego odnotowano stopę bezrobocia na poziomie $8,8-11,2 \%$. Najniższe bezrobocie w skali kraju zarejestrowano w województwach mazowieckim, wielkopolskim, dolnośląskim, śląskim i małopolskim (6,2-8,7\%) (GUS, 2015).

${ }^{5}$ Wyszczególnienie przyczyn tego stanu rzeczy wykracza poza ramy niniejszego artykułu. Warto zaznaczyć, że było to mocno związane z koniecznością wprowadzenia zmian w gospodarce po upadku ZSRR (m.in. wraz z transformacją upadło wiele firm, które prowadziły szkoły przyzakładowe bądź stanowiły źródło pracodawców dla absolwentów). 
w szkolnictwie ogólnokształcącym, nowo powstałym „ogólnozawodowym” i - docelowo wyższym (Osiecka-Chojnacka, 2007). W następnych dekadach doprowadziło to do znacznego zwiększenia współczynnika skolaryzacji w szkolnictwie wyższym, jednak kosztem odwrotu od szkolnictwa zawodowego (w tym znacznie obniżono finansowanie dla szkół o charakterze zawodowym, zmniejszono ich liczbę, a także nastąpił spadek zainteresowania młodzieży nauką w tych placówkach). Sytuacja na tym polu zaczęła się zmieniać dopiero w ostatnich latach $^{6}$ - najnowsza reforma kształcenia zawodowego z $2011 \mathrm{r}$. wprowadziła od roku szkolnego 2012/2013 m.in. efekty uczenia się, zmienione podstawy programowe, nową klasyfikację zawodów szkolnictwa zawodowego oraz nowe egzaminy zawodowe (Sławiński, Dębowski, 2013).

Jednak obecnie Polska nadal boryka się z pewnymi problemami w kształceniu zawodowym. Należy do nich m.in. niedopasowanie oferty szkół zawodowych (profili otwieranych klas) do popytu na specjalistów na lokalnym rynku oraz - będące szerszym zagadnieniem niedopasowanie umiejętności absolwentów szkół zawodowych do potrzeb rynku pracy (tzw. skills mismatch $)^{7}$. Inną kwestią jest niska jakość kształcenia w szkołach zawodowych, która $\mathrm{w}$ dużej mierze wynika $\mathrm{z}$ niedofinansowania. Za brakiem funduszy idzie natomiast niedostosowanie infrastruktury szkolnej (wyposażenia warsztatów pracy) do zmieniających się technologii. Dodatkowym problemem jest niski poziom doskonalenia i uaktualniania swoich kompetencji przez nauczycieli. Problemów tych nie można ekstrapolować na wszystkie polskie szkoły zawodowe, choć dotykają one wiele z nich.

Jeśli chodzi o zakładanie działalności gospodarczej w Polsce, można powiedzieć, że bywa to trudne nawet dla osób o wysokim potencjale przedsiębiorczym. Założenie własnej firmy jest procesem wieloetapowym i - mimo ułatwień wprowadzonych w ostatnich latach - nadal zbiurokratyzowanym ${ }^{8}$. W 2015 r. Polska zajmowała 85 miejsce w rankingu Banku Światowego pod względem łatwości zakładania przedsiębiorstw (World Bank, 2015). Ponadto jest to proces kosztowny. Otwarcie własnej działalności wymaga minimalnego kapitału początkowego w wysokości średnio 11,4\% dochodu per capita. Jednocześnie Bank Światowy ocenia łatwość pozyskania kredytu na 75 (w skali 0-100, gdzie 0 jest wynikiem najlepszym, a 100 - najgorszym) (World Bank, 2016). Wiąże się to m.in. z tym, że wiele instytucji finansowych w Polsce nie udziela kredytów firmom bez stażu rynkowego bądź udziela tylko niewielkich kredytów. Czynniki te niewątpliwie utrudniają absolwentom szkół zawodowych założenie własnej działalności gospodarczej, niezależnie od stopnia ich przygotowania do jej prowadzenia.

Jak wynika z powyższych danych oraz rozważań, przyczyn niskiego odsetka osób zakładających własną działalność gospodarczą jest wiele. Niewątpliwie potrzebne jest lepsze niż dotychczas przygotowywanie do wejścia na rynek pracy osób uczących się w ramach kształcenia

${ }^{6}$ Przykładem inicjatyw zmierzających do odbudowy znaczenia szkolnictwa zawodowego może być projekt systemowy „Szkoła zawodowa szkołą pozytywnego wyboru”, prowadzony w latach 2010-2013 w celu zwiększenia jakości kształcenia zawodowego i zainteresowania młodzieży tą formą kształcenia.

${ }^{7}$ Problem niedopasowania umiejętności do potrzeb rynku pracy dotyka nie tylko Polskę, lecz także całą Unię Europejską. Jest on zazwyczaj kojarzony z niewłaściwą ofertą edukacyjną bądź ofertą o niskiej jakości, jednak istotnym czynnikiem jest też migracja osób pracujących (rozłożenie umiejętności, tzw. skills distribution), w tym - odpływ osób z konkretnymi kompetencjami z danego rynku pracy (Cedefop, 2010).

${ }^{8}$ Wymaga m.in. otwarcia firmowego konta bankowego (w zależności od banku może być przy tym konieczne posiadanie pieczątki firmowej), uzyskania numeru NIP, wybrania właściwej formy opodatkowania (co z kolei wiąże się z wypełnieniem dodatkowych wniosków VAT), uzyskania numeru REGON w Głównym Urzędzie Statystycznym, złożenia wniosku rejestracyjnego w urzędzie gminy (przez Internet) a następnie zgłoszenia w ZUS-ie płatników składek. Jeśli firma nie jest działalnością jednoosobową i ma zatrudniać pracowników, konieczne jest także zgłoszenie w Państwowej Inspekcji Pracy oraz w sanepidzie. 
zawodowego. Może to poprawić sytuację absolwentów na tym rynku, pozytywnie wpłynąć na gospodarkę kraju, jak również podnieść atrakcyjność kształcenia zawodowego.

\section{Cele i formy kształcenia przedsiębiorczości}

Przedsiębiorczość jako przedmiot nauczania pojawiła się w Stanach Zjednoczonych w 1947 r. w Harvard Business School (Klucznik-Törő, 2012). Od tego czasu przedmiot ten zyskał popularność nie tylko w USA, lecz także w Europie. Obecnie w większości państw europejskich w ramach edukacji zawodowej realizuje się treści programowe dotyczące przedsiębiorczości.

Istnieją dwa podstawowe podejścia do kształcenia przedsiębiorczości: 1. jako jedna z kompetencji kluczowych - efekty uczenia się uzyskiwane są w ramach kilku przedmiotów (to podejście jest szczególnie często stosowane w edukacji podstawowej i na poziomie odpowiadającym polskiemu gimnazjum); 2. jako osobny przedmiot - częściej spotykane na poziomie edukacji ponadgimnazjalnej (European Commission, 2011).

W krajach, w których przedsiębiorczość pojawia się na wcześniejszych etapach edukacji, z reguły nie uczy się jej pod kątem praktyk biznesowych. Zaś w krajach, w których przedsiębiorczość jest nauczana w ramach odrębnego przedmiotu, często ma ona charakter nieobowiązkowy. Przedsiębiorczość jest nauczana w ramach wydzielonego przedmiotu w kilkunastu krajach europejskich. W Austrii, Walonii (Belgia), na Litwie, w Norwegii, Słowenii, Szwecji i Turcji jest to przedmiot nieobowiązkowy, natomiast m.in. w Estonii, Hiszpanii i Polsce obowiązkowy (Barabasch, 2014).

Wyniki badań potwierdzają jednak, że obligatoryjność czy fakultatywność kształcenia przedsiębiorczości nie odgrywa roli decydującej, jeśli chodzi o efektywność. Z raportu Global Entrepreneurship Monitor z 2008 r. wynika, że (uśredniając wyniki dla wszystkich badanych państw) osoby w wieku 18-64 lat, które dobrowolnie odbyły szkolenie z zakresu przedsiębiorczości, częściej planują założenie działalności w ciągu najbliższych trzech lat (średnia krajowa: 44,8\%) lub już aktywnie nad tym pracują (średnia krajowa: 21,6\%) niż osoby, które odbyły szkolenie obowiązkowe (odpowiednio średnia krajowa: $34,7 \%$ oraz $17,5 \%$ ). Jednak dla poszczególnych państw wyniki te kształtują się bardzo różnie (Bosma i in., 2008).

Rozbieżności w celach i formach nauczania przedsiębiorczości są konsekwencją różnego jej rozumienia i różnego stopnia rozwoju strategii związanych z jej kształceniem. W większości państw europejskich nauczanie przedsiębiorczości jest inicjatywą oddolną, przebiegającą przy minimalnym udziale państwa (European Commission, 2011).

Polska stanowi ciekawy przykład w tym kontekście. Kształcenie kompetencji związanych z przedsiębiorczością przebiega na wszystkich poziomach edukacji (European Commission, 2011). W szkołach zawodowych przedsiębiorczości naucza się od lat 90. XX w. Obecnie treści programowe związane z przedsiębiorczością są wykładane w ramach obowiązkowego przedmiotu podstawy przedsiębiorczości. Ich uzupełnieniem jest nieobowiązkowy przedmiot ekonomia w praktyce. Oba są realizowane w szkołach ponadgimnazjalnych (a więc także o charakterze zawodowym) w oparciu o podstawę programową kształcenia ogólnego (PPKO). Na przedmiot podstawy przedsiębiorczości przewidziano 60 godzin. Cele kształcenia obejmują kompetencje związane z: 1. komunikacją i podejmowaniem decyzji, 2. gospodarką i przedsiębiorstwem, 3. planowaniem i karierą zawodową oraz 4. zasadami etycznymi. Przedmiot uzupełniający ekonomia w praktyce ma na celu „nabycie umiejętności przeprowadzenia kompletnej realizacji przedsięwzięcia: od pomysłu, przez przygotowanie planu, wdrożenie go, aż do 
analizy efektów" (PPKO). Wymagania szczegółowe obejmują: 1. planowanie przedsięwzięcia uczniowskiego o charakterze ekonomicznym, 2. analizę rynku, 3. organizację przedsięwzięcia, 4. ocenę efektów działań (obejmującą m.in. ocenę możliwości realizacji przedsięwzięcia uczniowskiego w rzeczywistych warunkach gospodarczych). Ponadto, w ramach przedmiotów ogólnozawodowych realizowane są treści związane z podejmowaniem i prowadzeniem działalności gospodarczej, kompetencjami personalnymi i społecznymi, organizacją pracy małych zespołów. W podstawie programowej kształcenia zawodowego, wdrażanej od 2012 r., efekty kształcenia pogrupowano na: 1. wspólne dla wszystkich zawodów, 2. wspólne dla zawodów w ramach branży i 3. właściwe dla określonego zawodu. Wyżej wymienione treści należą do efektów wspólnych dla wszystkich zawodów. Do tej grupy zalicza się jeszcze bezpieczeństwo i higienę pracy oraz język obcy ukierunkowany zawodowo. Wymienione powyżej efekty uczenia się są sprawdzane na egzaminach potwierdzających kwalifikacje w zawodach.

Polski system nauczania przedsiębiorczości w ramach kształcenia zawodowego ma więc charakter mieszany: treści nauczania dotyczące przedsiębiorczości są realizowane w ramach odrębnego, obowiązkowego przedmiotu, w ramach przedmiotu uzupełniającego, nieobowiązkowego, jak również w ramach innych przedmiotów.

Wydaje się zatem, że cele i formy nauczania przedsiębiorczości w polskim systemie kształcenia zawodowego są skonstruowane kompleksowo i umożliwiają uczniom rozwijanie podstawowej wiedzy, umiejętności i kompetencji związanych z przedsiębiorczością. Analiza celów i form nauczania jest cenna z naukowego punktu widzenia, ponieważ to one są punktem wyjścia do nauczania przedsiębiorczości, to one tworzą ramy, w jakich funkcjonują i kształcą nauczyciele. Elementów tych nie można więc pomijać, a ich znaczenia podważać, ale są one zdecydowanie niewystarczające do oceny efektywności nauczania. Są to bowiem jedynie ogólne wytyczne i założenia teoretyczne, od których praktyka może znacząco odbiegać. To od szkół i nauczycieli zależy, jak są realizowane treści nauczania. Kluczową rolę odgrywają tu stosowane metody, kompetencje nauczycieli i współpraca z rynkiem pracy.

\section{Metody kształcenia przedsiębiorczości}

Niezależnie od typu edukacji - zawodowej czy ogólnej - do realizacji celów zdefiniowanych dla kształcenia przedsiębiorczości najbardziej efektywnym podejściem jest uczenie się przez działanie (ang. learning by doing) (European Commission, 2009). Definiowane jest ono jako „uczenie się poprzez zdobywanie doświadczenia wynikającego bezpośrednio z własnych działań. Przeciwstawia się to uczeniu się na drodze obserwacji pracy innych, czytania lub słuchania instrukcji, a także wykładów" (Reese, 2011: 1; tłum. własne). Felix Rauner i Rupert Maclean (2008: 538) zaznaczają ponadto, że liczne teorie i badania wykazują, iż „zdobywanie kompetencji nie może być odseparowane od ich praktycznego stosowania. Kompetencje zależą od kontekstu (warunków), w jakim zostały nabyte, i kontekstu, w jakim mają być wykorzystywane - konteksty te powinny być zbliżone" (tłum. własne). Efektywność podejścia learning by doing została potwierdzona przez wiele badań, m.in. przeprowadzonych na North Carolina State University (Richardson, 1994).

Takie podejście do nauczania przedsiębiorczości w ramach kształcenia zawodowego jest szczególnie skuteczne i uzasadnione. Możliwe jest bowiem łączenie kształcenia elementów przedsiębiorczości ze zdobywaniem kompetencji zawodowych poprzez uczenie się ukierunkowane na wykonywanie zadań (ang. task-oriented learning) zawodowych i rozwiązywanie napotykanych $\mathrm{w}$ ich ramach problemów. Zadania powinny być wybierane spośród działań 
typowych dla danego zawodu, zaczerpnięte z codziennej działalności przedsiębiorstwa z danej branży. Mogą być wykonywane w miejscu pracy lub w warunkach zbliżonych do realnych. Pozwala to uczniom zrozumieć, po co się uczą i do czego przydadzą im się nabyte kompetencje. Dzięki temu będą przyzwyczajani do poszukiwania różnych rozwiązań, pracy zespołowej, analizowania swoich działań, a co za tym idzie - podejmowania bardziej przemyślanych decyzji. Podejście to podnosi motywację do uczenia się i lepiej przygotowuje uczniów do przyszłej pracy (Rauner, Maclean, 2008), zwiększając szanse i możliwości młodych osób na rynku pracy. Można uznać je za kluczowe dla rozwijania przedsiębiorczej postawy i sposobu myślenia (ang. entrepreneurial mindset) oraz kompetencji w zakresie przedsiębiorczości (European Commission, 2009).

Podejście do nauczania przekłada się bezpośrednio na stosowane metody. Jak wynika z badania Komisji Europejskiej, w szkołach w Europie najczęściej stosowane są: wykłady, symulacje komputerowe i gry biznesowe, zakładanie firm studenckich, praca w grupach i w ramach projektów, wizyty w przedsiębiorstwach oraz odbywanie praktyk. Rzadziej stosuje się: coaching, mentoring, odgrywanie ról, dyskusje, „burze mózgów” i studia przypadków (European Commission, 2009). Metody nauczania odwołujące się do uczenia się przez działanie i ukierunkowane na wykonywanie zadań są zatem wykorzystywane, jednak wciąż nie należą do najczęściej stosowanych.

W nauczaniu przedsiębiorczości (uwzględniając specyfikę polskiego szkolnictwa zawodowego oraz potrzeby rynku pracy) szczególnie efektywne mogą okazać się metody wykorzystujące angażowanie uczniów w różnego typu aktywności organizowane w klasie (ang. in-class activities), np. praca w grupach czy rozwiązywanie problemów. Efektywność tego podejścia potwierdzają badania przeprowadzone przez naukowców z Murray State University i Saint Louis University (Hackathorn i in., 2011). Analizowali oni także takie metody, jak wykład, dyskusja i demonstracja, wykazując, że wykłady są najmniej efektywną metodą nauczania, a najbardziej skuteczne jest wykorzystywanie różnych metod w toku edukacji.

Szczególne zastosowanie mogą mieć metody bazujące na współpracy (ang. collaborative learning, cooperative learning), zarówno między uczniami, jak i między uczniem a np. przedsiębiorcą. Efektywność collaborative learning i cooperative learning potwierdzono w licznych badaniach (Prince, 2004). Metody te przeciwstawiane są pracy indywidualnej ucznia i konkurowaniu między uczniami, co okazuje się mniej efektywne niż uczenie się przez współpracę. Ponadto mogą one rozwijać w uczniach kompetencje pożądane przez polskich pracodawców, tj. kompetencje interpersonalne czy umiejętność pracy w grupie. Do metod tych w kontekście kształcenia przedsiębiorczości zaliczyć można pracę w ramach projektów i firm uczniowskich.

W Polsce jest niewiele badań na temat wykorzystywania metod nauczania przedsiębiorczości. Jedno z nich, przeprowadzone przez Tomasza Rachwała i Mariolę Tracz (2008), wskazuje, że sytuacja w Polsce nie wygląda źle, ale wymaga poprawy. Tylko 12,8\% badanych nauczycieli bardzo często stosuje metody aktywizujące w ramach nauczania przedsiębiorczości, $44,1 \%$ robi to często, 20\% - czasami, a 23,1\% - rzadko (badanie przeprowadzono wśród 215 nauczycieli podstaw przedsiębiorczości wszystkich typów szkół ponadgimnazjalnych na terenie 8 województw).

Niedostateczne stosowanie efektywnych metod nauczania przedsiębiorczości wynika przede wszystkim z niewystarczającej wiedzy wśród nauczycieli na temat takich metod oraz specyfiki kształcenia przedsiębiorczości ${ }^{9}$. Wskazuje się, że nauczyciele przedsiębiorczości

\footnotetext{
${ }^{9}$ Według Komisji Europejskiej nauczycielom często brakuje kompetencji odpowiednich do nauczania przedsiębiorczości (European Commission, 2009). W państwach UE tematyka przedsiębiorczości nie jest obowiązkowym
} 
w ramach kształcenia zawodowego powinni pełnić funkcję bardziej trenera, facylitatora niż wykładowcy. Po drugie, przyczyną takiej sytuacji bywa niedostateczna komunikacja lub brak chęci współpracy między nauczycielami, którzy mogliby realizować wspólne projekty w ramach swoich przedmiotów, w tym przedmiotu dotyczącego przedsiębiorczości (lub zagadnień z tym związanych). Nawiązanie takiej współpracy utrudnia brak interdyscyplinarnego podejścia w kształceniu zawodowym (European Commission, 2009; Barabasch, 2014).

Stosowanie omówionych metod pozytywnie wpływa na wykształcenie w uczniach takich kompetencji, jak samodzielność, kreatywność i dobra organizacja pracy, a właśnie na takie cechy szczególną uwagę zwracają pracodawcy. Są to najbardziej pożądane i najczęstsze wymagania kompetencyjne na rynku pracy - oczekuje ich 54\% pracodawców. Następne są kompetencje interpersonalne - wymaga ich 36\% pracodawców, jednocześnie ponad $25 \%$ polskich pracodawców deklaruje, że brak tych kompetencji stanowi dla nich przeszkodę w znalezieniu odpowiednich kandydatów do pracy (Kocór, Strzebońska, Dawid-Sawicka, 2015). Dlatego dobór odpowiednich metod kształcenia jest tak ważny z punktu widzenia sytuacji absolwentów na rynku pracy.

Jak już wspomniano, jednym z najskuteczniejszych podejść w nauczaniu przedsiębiorczości jest learning by doing, a kontekst (warunki), w jakim zdobywa się kompetencje, powinien być zbliżony do tego, w którym będą wykorzystywane - w działalności zawodowej, na rynku pracy. Stąd bardzo cennym elementem kształcenia przedsiębiorczości jest angażowanie w nie przedsiębiorstw (praktyki, wizyty w firmach) oraz przedsiębiorców (prowadzenie przez nich lekcji, spotkania z uczniami, coaching, mentoring). Dodatkowo, aby zwiększać przydatność edukacji przedsiębiorczości, trzeba powiązać ją z rynkiem pracy, tak by odpowiadała na jego potrzeby. Przyczynić się do tego mogą konsultacje programu nauczania z przedstawicielami pracodawców. Za najbardziej efektywne i korzystne dla uczniów uznaje się włączanie ich w prace mikro, małych i średnich firm, ale często współpraca właśnie z tym sektorem bywa też problematyczna ze względu na ograniczone zasoby ludzkie i finansowe, a co za tym idzie, brak czasu.

W państwach europejskich na drodze do współpracy z przedsiębiorcami nie stoją żadne bariery administracyjne i w wielu krajach, szczególnie tych, gdzie funkcjonuje system dualny (Austria, Niemcy, Dania), współpraca szkół z pracodawcami jest owocna. Staże i praktyki u przedsiębiorców są obowiązkowe w takich państwach, jak Bułgaria, Dania, Hiszpania, Finlandia, Cypr, Luksemburg, Wielka Brytania, Słowenia czy Malta. Wizyty w przedsiębiorstwach i zajęcia prowadzone przez przedsiębiorców są najbardziej popularne w Belgii, Danii, Holandii i na Malcie. W Polsce taka współpraca nie jest uregulowana prawnie i zależy jedynie od inicjatywy szkoły i nauczycieli (European Commission, 2009; Cedefop, 2011).

Bezpośrednie kontakty z przedsiębiorcami pomagają uczniom odnaleźć się na rynku pracy, uświadamiają, że założenie własnej firmy może być sposobem na życie i pobudzają do podejmowania takiej inicjatywy. Przynosi to większe korzyści niż zakładanie działalności pod presją sytuacji ekonomicznej. Badania pokazują, że kraje, gdzie większość działań przedsiębiorczych jest motywowana bardziej przez rozpoznanie ekonomicznych możliwości (ang. opportunity entrepreneurship) niż przez konieczność (ang. necessity entrepreneurship), mają wyższy poziom dochodów (Bosma i in., 2008).

elementem w ramach ścieżki edukacyjnej nauczycieli kształcenia zawodowego. Ponadto przygotowanie ich do nauczania przedsiębiorczości ma często charakter ad hoc (np. w formie kursów). W konsekwencji nauczyciele mogą nie być świadomi właściwego podejścia do kształcenia w zakresie przedsiębiorczości - zarówno w odniesieniu do treści nauczania, celów, jak i najbardziej efektywnych metod (Cedefop, 2011). 


\section{Podsumowanie}

Jak wskazuje Komisja Europejska, aby zapewnić efektywność edukacji przedsiębiorczości, konieczne jest włączenie jej we wszystkie etapy i aspekty edukacji zawodowej. Uznaje się to za ważniejsze niż tworzenie odrębnego przedmiotu (European Commission, 2010). Należy zatem postawić pytanie, czy 60-godzinny przedmiot spełnia to zalecenie. O tym, czy nauczanie przedsiębiorczości jest włączane we wszystkie aspekty kształcenia zawodowego, w praktyce decydują dyrektorzy szkół i nauczyciele i ich podejście do realizowanego przedmiotu. Antje Barabasch (2014) twierdzi nawet, że w przypadku edukacji przedsiębiorczości wykorzystywane metody nauczania są bardziej istotne niż treści kształcenia.

Przeprowadzona analiza pozwala stwierdzić, że forma nauczania przedsiębiorczości w małym stopniu decyduje o efektywności tej edukacji. Kluczowe są metody nauczania, a ich dobór w toku kształcenia zawodowego może w istotny sposób wpływać na sytuację absolwentów na rynku pracy. Stosowane metody oddziałują na kształtowanie wiedzy, umiejętności i kompetencji społecznych uczniów. Metody, które najlepiej przysposabiają uczniów szkół zawodowych i technikum do przyszłej pracy, to te o charakterze praktycznym i angażującym uczniów, czyli bazujące na uczeniu się przez własne działanie, rozwiązywaniu problemów, współpracy w ramach projektów szkolnych oraz współpracy z przedsiębiorcami.

Wykorzystywane metody wynikają z kompetencji i zaangażowania nauczycieli oraz podejścia nauczycieli i szkoły do współpracy z przedsiębiorcami. Należy wybierać takie metody, które będą pobudzały kreatywność i samodzielność. Szkoły i nauczyciele powinni zadbać, aby na każdym etapie kształcenia zawodowego nauczanie przedsiębiorczości było obecne, a cele tej edukacji były realizowane jednocześnie z rozwijaniem umiejętności zawodowych.

Wszelkie aktywności umożliwiające uczniom poznanie sposobu funkcjonowania firmy (praktyki w realnych firmach lub zakładanie firm uczniowskich) uzmysławia im, że własna działalność gospodarcza jest możliwą i ciekawą opcją kariery. Szkoła odgrywa w tym procesie ważną rolę, ponieważ odpowiada za zorganizowanie warunków sprzyjających nauce, ale to nauczyciele pełnią funkcję przewodnika i mentora dla uczniów, i dlatego ich kompetencje są kluczowe. Szkolenie nauczycieli w zakresie przedsiębiorczości powinno być obowiązkowe (podejście systemowe). Ważne jest, aby nauczyciele przeszli przez ten sam proces uczenia się, jaki później będą realizować ze swoimi uczniami. Dodatkowo, nauczyciele powinni być przygotowywani do nauczania przedsiębiorczości - zarówno w toku swoich studiów, jak i okresowo po rozpoczęciu pracy w zawodzie. Pozwoliłoby to na aktualizację ich kompetencji (podejście systematyczne). Ponadto szkolenie nauczycieli powinno prowadzić do rozwijania w nich, obok kompetencji pedagogicznych, także umiejętności związanych z zarządzaniem projektami w zakresie wspierania uczniów oraz umiejętności personalnych (European Commission, 2009).

Komisja Europejska, podsumowując edukację przedsiębiorczości w Polsce w 2009 r., stwierdziła, że podejście do nauczania przedsiębiorczości w naszym państwie jest raczej teoretyczne. Uczniowie zdobywają umiejętności zawodowe podczas odbywania praktyk w miejscu pracy, ale w ich trakcie nie są rozwijane kompetencje związane z przedsiębiorczością (European Commission, 2009). Jednak zmieniona w 2008 r. podstawa programowa kształcenia ogólnego położyła duży nacisk na kształtowanie umiejętności przydatnych na rynku pracy, w tym m.in. na umiejętność podejmowania decyzji, planowanie działań i swojej kariery zawodowej. Jednak na ocenę skuteczności wprowadzonych zmian i ich wpływu na sytuację absolwentów na rynku pracy jest jeszcze za wcześnie. 
Literatura

References

Barabasch, A. (2014). Entrepreneurship education in Vocational Education \& Training (VET). W: M.C.

Pantea (red.), Young people, entrepreneurship \& non-formal learning: a work in progress. SALTO-Youth, $171-182$.

Borowiec, M. (2008). Rola szkolnictwa wyższego w procesie kształtowania gospodarki opartej na wiedzy. Przedsiębiorczość - Edukacja, 4, 24-36.

Borowiec, M. (2009). Rola edukacji w kształtowaniu społeczeństwa informacyjnego. Przedsiębiorczość Edukacja, 5, 37-47.

Bosma, N., Acs, Z.J., Autio, E., Coduras, A., Levie, J. (2008; 2016, 28 lipca). Global Entrepreneurship Monitor: 2008 Executive Report. Pozyskano z: http://www.gemconsortium.org/report

Cedefop (2010). The skill matching challenge. Analysing skill mismatch and policy implications. Luxembourg: Publications Office.

Cedefop (2011). Guidance supporting Europe's aspiring entrepreneurs. Policy and practice to harness future potential. Research Paper, 14. Luxembourg: Publications Office

CEIDG - Centralna Ewidencja i Informacja o Działalności Gospodarczej. Pozyskano z: https://prod. ceidg.gov.pl/ceidg.cms.engine/

Cichocki, S., Popowski, P., Skibińska, M., Strzelecki, P., Tyrowicz, J., Wyszyński, R. (2015). Kwartalny raport o rynku pracy w II kwartale 2015 r. Warszawa: Narodowy Bank Polski.

Cieślik, J. (2014). Przedsiębiorczość, polityka, rozwój. Warszawa: Wydawnictwo Akademickie SEDNO.

Desperak, J., Depczyńska, A. (2007). Przedsiębiorczy uczeń w UE - propozycje tematów lekcji. Przedsiębiorczość - Edukacja, 3, 325-331.

Dorocki, S., Kilar, W., Rachwał, T. (2011). Założenia i cele Projektu „Krok w przedsiębiorczość” dla nauczycieli szkół ponadgimnazjalnych. Przedsiębiorczość - Edukacja, 7, 308-320.

European Commission (2009, 2016, 28 lipca). Entrepreneurship in Vocational Education and Training. Final report of the Expert Group. Pozyskano z: http://ec.europa.eu/DocsRoom/documents/10446?locale $=\mathrm{pl}$

European Commission (2011, 2016, 28 lipca). Entrepreneurship education: Enabling teachers as a critical success factor. A report on teacher education and training to prepare teachers for the challenge of entrepreneurship education. Pozyskano z: http://ec.europa.eu/DocsRoom/documents/9272/attachments/1/translations/en/renditions/native

European Commission (2014; 2016, 28 lipca). SME Performance review. Database for the annual report 2014 [zbiór danych]. Pozyskano z: http://ec.europa.eu/growth/smes/business-friendly-environment/performance-review_en

Eurostat (2015; 2016, 28 lipca). Youth unemployment rate and ration, 2011-13. Pozyskano z: http:// ec.europa.eu/eurostat/statistics-explained/index.php/File:Youth_unemployment_rate_and_ratio,_2011-13_\%28\%25\%29_YB15.png

Eurostat (2016, 28 lipca). Unemployment rate by sex and age - monthly average. Pozyskano z: http:// appsso.eurostat.ec.europa.eu/nui/show.do?wai=true\&dataset=une_rt_m

Główny Urząd Statystyczny (2015a, 2016, 28 lipca). Aktywność ekonomiczna ludności Polski. IV kwartat 2015 [zbiór danych]. Pozyskano z: http://stat.gov.pl/obszary-tematyczne/rynek-pracy/pracujacy-bezrobotni-bierni-zawodowo-wg-bael/aktywnosc-ekonomiczna-ludnosci-polski-iv-kwartal-2014-r-,4,15.html

Główny Urząd Statystyczny (2015b; 2016, 28 lipca). Bezrobocie rejestrowane. I-III kwartał 2015. http:// stat.gov.pl/obszary-tematyczne/rynek-pracy/bezrobocie-rejestrowane/bezrobocie-rejestrowane-i-iii-kwartal-2015-r-,3,21.html

Główny Urząd Statystyczny (2015c; 2016, 28 lipca). Stopa bezrobocia w latach 1990-2015. Pozyskano z: http://stat.gov.pl/obszary-tematyczne/rynek-pracy/bezrobocie-rejestrowane/stopa-bezrobocia-w-latach-1990-2016,4,1.html 
Hackathorn, J., Solomon, E., Blankmeyer, K., Tennial, R., Garczynski, A. (2011). Learning by doing: An empirical study of active teaching techniques. The Journal of Effective Teaching, 11(2), 40-54.

Jelonek, M., Kasparek, K., Magierowski, M. (2015). Młodzi na rynku pracy - pracownicy, przedsiębiorcy, bezrobotni. Na podstawie analizy kierunków kształcenia zrealizowanej w 2014 roku w ramach $V$ edycji projektu Bilans Kapitatu Ludzkiego. Edukacja a rynek pracy - tom IV. Warszawa: Polska Agencja Rozwoju Przedsiębiorczości.

Klucznik-Törő, A. (2012; 2016, 28 lipca). Nauczanie przedsiębiorczości w świetle światowej literatury przedmiotu. E-mentor, 5(47). http://www.e-mentor.edu.pl/artykul/index/numer/47/id/966\#top

Kocór, M., Strzebońska, A., Dawid-Sawicka, M. (2015). Rynek pracy widziany oczami pracodawców. Na podstawie badań pracodawców i fert pracy zrealizowanych $w 2014$ roku w ramach V edycji projektu Bilans Kapitału Ludzkiego. Edukacja a rynek pracy - tom I. Warszawa: Polska Agencja Rozwoju Przedsiębiorczości.

Ministerstwo Edukacji Narodowej i Krajowy Ośrodek Wspierania Edukacji Zawodowej i Ustawicznej (201; 2016, 28 lipca 1). Badanie funkcjonowania systemu kształcenia zawodowego w Polsce. Raport końcowy. Pozyskano z: http://biblioteka-krk.ibe.edu.pl/opac_css/doc_num.php?explnum_id=104

OECD (2009; 2016, 28 lipca). Measuring Entrepreneurship. A Collection of Indicators, OECD-Eurostat Entrepreneurship Indicators Programme. Pozyskano z: http://www.insme.org/files/3862

Osiecka-Chojnacka, J. (2007). Szkolnictwo zawodowe wobec problemów rynku pracy. Infos, 16.

Piróg, D. (2005). Miejsce i rola edukacji europejskiej w nauczaniu podstaw przedsiębiorczości w kontekście współczesnych wyzwań cywilizacyjnych. Przedsiębiorczość - Edukacja, 1, 213-220.

Piróg, D. (2010). Studia wyższe a rynek pracy w Polsce - zarys stanu badań. W: B. Sitarska, K. Jankowski, R. Droba (red.), Studia wyższe z perspektywy rynku pracy. Siedlce: Wydawnictwo Akademii Podlaskiej, 67-80.

Piróg, D. (2015). Kompetencje z zakresu przedsiębiorczości: rozważania teoretyczne i ich ilustracje w bszarze szkolnictwa wyższego. Przedsiębiorczość - Edukacja, 11, 364-376.

Prince, M. (2004). Does active learning work? A review of the research. Journal of Engineering Education, 93(3), 223-231.

Rachwał, T. (2009). Ocena projektu zmian podstawy programowej podstaw przedsiębiorczości. Przedsiębiorczość - Edukacja, 5, 349-373.

Rachwał, T., Kudełko, J., Tracz, M., Wach, K., Kilar, W. (2008). Projekt podstawy programowej podstaw przedsiębiorczości w zakresie rozszerzonym dla liceum ogólnokształcącego, liceum profilowanego i technikum. Przedsiębiorczość - Edukacja, 4, 312-324.

Raczyk, A. (2009). Metody badania przedsiębiorczości oparte na rejestrze podmiotów gospodarki narodowej. Przedsiębiorczość - Edukacja, 5, 133-146.

Rauner, F., Maclean, R. (red.). (2008). Handbook of Technical and Vocational Education and Training Research. Springer Science+Business Media B.V.

Reese, H.W. (2011). The learning-by-doing principle. Behavioral Development Bulletin, 11, 1-19.

Richardson, J. (1994; 2016, 28 lipca). Learning best through experience. Journal of Extension, 32(2). Pozyskano z: http://www.joe.org/joe/1994august/a6.php

Rozporządzenie Ministra Edukacji Narodowej z dnia 23 grudnia 2008 r. w sprawie podstawy programowej wychowania przedszkolnego oraz kształcenia ogólnego w poszczególnych typach szkół (Dz.U. z 2009 r. Nr 4, poz. 17).

Rozporządzenie Ministra Edukacji Narodowej z dnia 7 lutego 2012 r. w sprawie podstawy programowej kształcenia w zawodach (Dz.U. z 2012 r., poz. 184).

Sławiński, S., Dębowski, H. (red.). (2013). Raport referencyjny. Odniesienie Polskiej Ramy Kwalifikacji na rzecz uczenia się przez całe życie do Europejskiej Ramy Kwalifikacji. Warszawa: IBE.

Tarnawa, A., Zadura-Lichota, P. (2015). Raport o stanie sektora małych i średnich przedsiębiorstw w Polsce w latach 2013-2014. Warszawa: Wydawnictwo Naukowe Instytutu Technologii i Eksploatacji, Polska Agencja Rozwoju Przedsiębiorczości. 
Tarnawa, A., Zadura-Lichota, P., Zbierowski, P., Nieć, M. (2014). Global Entrepreneurship Monitor: Polska. Raport $z$ badań 2013. Warszawa: Wydawnictwo Naukowe Instytutu Technologii i Eksploatacji, Polska Agencja Rozwoju Przedsiębiorczości.

Tracz, M., Rachwał, T. (2008). Metody nauczania i środki dydaktyczne stosowane przez nauczycieli podstaw przedsiębiorczości - wyniki badań. Przedsiębiorczość - Edukacja, 4, 324-330.

World Bank (2015; 2016, 28 lipca). Economy rankings. Pozyskano z: http://www.doingbusiness.org/ rankings

World Bank (2016, 28 lipca). Doing Business 2016: measuring regulatory quality and efficiency. World Bank, 227. Pozyskano z: http://www.doingbusiness.org/ /media/GIAWB/Doing\%20Business/ Documents/Annual-Reports/English/DB16-Full-Report.pdf

Zioło, Z. (2012). Miejsce przedsiębiorczości w edukacji. Przedsiębiorczość - Edukacja, 8, 10-23.

Agata Poczmańska, główny specjalista ds. badań i analiz w Instytucie Badań Edukacyjnych. Zajmuje się Zajmuje się opisywaniem kwalifikacji nadawanych poza systemami oświaty i szkolnictwa wyższego oraz projektowaniem podejścia do formułowania efektów uczenia się. Prowadzi badania i analizy w obszarze kształcenia zawodowego i zagranicznych systemów kwalifikacji. Jako stażystka w Europejskim Centrum Rozwoju Kształcenia Zawodowego (Cedefop), agencji Unii Europejskiej, przez rok prowadziła analizy dotyczące kwalifikacji międzynarodowych. Pracowała też nad ewaluacją wizyt studyjnych. Przez trzy poprzedzające lata pracowała w Związku Rzemiosła Polskiego (w Zespole Koordynacji Spraw Europejskich). Ukończyła europeistykę na Wydziale Dziennikarstwa i Nauk Politycznych Uniwersytetu Warszawskiego, gdzie obecnie jest doktorantką. Jej zainteresowania badawcze koncertują się na tematyce edukacji, przedsiębiorczości, innowacyjności, funduszy unijnych oraz instytucji Unii Europejskiej.

Agata Poczmańska, chief specialist for research and analysis in the Educational Research Institute. She is working on the qualification designing and development including the approach to formulating learning outcomes. She conducts research and analysis in the field of vocational education and training and foreign qualifications systems. As a trainee in the European Centre for the Development of Vocational Training (Cedefop) she was dealing with identifying and analysing international qualifications and also with the impact assessment of study visits. Before that, for three years she had been working for Polish Craft Association (Department for Coordination of European Affairs). She graduated with a Master's degree in European Studies at the Faculty of Journalism and Political Sciences at the University of Warsaw, where currently she is a $\mathrm{PhD}$ student. Her research interests are focused on education, entrepreneurship, innovation, UE funds and UE institutions.

\section{Adres/Address:}

Instytut Badań Edukacyjnych

ul. Górczewska 8

01-180 Warszawa, Polska

e-mail: a.poczmanska@ibe.edu.pl

Roksana Pierwieniecka od 2011 r. zajmuje się zintegrowanym system kwalifikacji. W tym czasie należała do zespołów, które opracowywały założenia merytoryczne tego systemu (w tym Polskiej Ramy Kwalifikacji), przygotowywały polski raport referencyjny, a także wytyczne dotyczące walidacji efektów uczenia się uzyskanych poza edukacją formalną. Prowadziła desk research oraz przygotowywała opracowania na temat m.in.: uczenia się w miejscu pracy, współpracy pracodawców z instytucjami kształcącymi, tworzenia standardów kompetencji zawodowych i kwalifikacji zawodowych, zapewniania jakości w kształceniu zawodowym, walidacji kompetencji uzyskanych poza edukacją formalną (w tym stosowanych metod, osób prowadzących ten proces, procedur, systemów w innych krajach).

Roksana Pierwieniecka has been involved in work on the Polish Qualifications System since 2011. During that time she was a member of teams responsible for: developing assumptions of national qualifications system (including Polish Qualifications Framework) and Polish Referencing Report and guidelines 
for validation of non-formal and informal learning. She has conducted desk research and prepared written materials, among others, on: work-based learning, cooperation between stakeholders and VET providers, developing VET standards and qualifications, quality assurance of VET provision and validation of non-formal and informal learning (in regards to methods used, practitioners, procedures, country systems, etc.).

\section{Adres/Address:}

Instytut Badań Edukacyjnych

ul. Górczewska 8

01-180 Warszawa, Polska

e-mail: r.pierwieniecka@ibe.edu.pl 